\title{
Effects of Long-term Grazing on Cryptogam Crust Cover in Navajo National Monument,
} Ariz.

\author{
JACK D. BROTHERSON, SAMUEL R. RUSHFORTH, AND JEFFREY R. JOHANSEN
}

\section{Abstract}

The effects of long-term grazing ( 40 years) on cryptogamic crusts of Navajo National Monument were investigated. Both vascular and nonvascular communities were heavily impacted with the cryptogamic community showing the greatest reduction in cover. Lichens and mosses were the most damaged, while the algae were much more tolerant. Individual cryptogam species were affected in similar patterns with all identifiable species showing reduced cover. Vascular plant species were also affected with grasses showing the greatest reduction under grazing pressure.

Throughout desert systems of western North America there is scant ground cover and often extensive open areas between the plants. In such open areas, soils are exposed to powerful erosive impacts. When soils are unprotected, erosion can be extensive and soil losses can be great. Of primary importance in the protection of desert soils are communities of nonvascular cryptogamic plants that grow upon or immedia tely beneath the soil surface. When well established and undisturbed such plants form a crust which plays an important role in soil stabilization (Fletcher and Martin 1948; Kleiner and Harper 1972, 1977; Loope and Gifford 1972; Anderson et al. 1982a, 1982b).

Algae are the primary components of these crusts but they are often accompanied by lichens and mosses (Anderson and Rushforth 1977, Kleiner and Harper 1972). Algae are the most effective in binding the soil particles (Anantani and Marathe 1974, Anderson and Rushforth 1976). Where cryptogam crusts are well developed the soil surface is almost always highly stable.

Research has been done on several aspects of the biology of soil crusts and cryptogamic communities. Ecological relationships have been studied by Anderson et al. (1982a) and Anderson et al. (1982b). Species composition and taxonomic relationships of crusts were studied by Anderson and Rushforth (1976). The role of such crusts in nitrogen fixation was studied by Rychert and Skujins (1974) and their effects on infiltration and sedimentation by Loope and Gifford (1972). However, much is yet to be learned about the role of these crusts in desert ecosystems.

The Navajo National Monument boundary (fenceline) provided an excellent opportunity to evaluate the effects of grazing on the cryptogamic soil crusts of the pinyon-juniper zone in northeastern Arizona. The objective of this study was to evaluate the effects of long-term grazing (40 years) on the cryptogamic soil cover of the pinyon-juniper zone in northern Arizona (Navajo National Monument).

\section{Study Area}

Navajo National Monument is located in northeastern Arizona

\footnotetext{
Authors are professors of botany and range science, Department of Botany and Range Science, Brigham Young University, Provo, Utah 84602 and graduate student, Department of Botany and Range Science, Brigham Young University, Provo, Utah 84602 .

Manuscript received March, 3, 1983.
}

about $30 \mathrm{~km}$ southwest of the village of Kayenta and is the site of three large Anasazi Indian cliff dwellings (ruins). Betatakin Canyon, the site of the present study, is a side canyon of the larger Tsegi Canyon complex and has been described by Hack (1945). The major geological formation within the canyon is Navajo Sandstone, which forms sheer towering cliffs $200 \mathrm{~m}$ or more in height. The canyon floor consists of alluvial deposits of sandy Quaternary fill. Kayenta Sandstone forms outcrops in the lower reaches of the canyon.

The annual temperatures recorded at park headquarters at Betatakin Canyon range from $-23^{\circ} \mathrm{C}$ to $38^{\circ} \mathrm{C}$ with a mean of $10^{\circ} \mathrm{C}$. The number of frost-free days in the area varies from 107 to 213 , with an average of 155 days. Annual precipitation ranges from 17 $\mathrm{cm}$ to $48 \mathrm{~cm}$ with a mean of $29 \mathrm{~cm}$. There is a single wet season, lasting from late summer to fall.

A mature pinyon-juniper commuity occurs on the mesas and slopes above the canyon and extends onto the large areas of exposed slickrock along the canyon edges. Pinyon pine (Pinus edulis) and Utah juniper (Juniperus osteosperma) a re consistently the dominant overstory species of this community.

The understory is dominated by a variety of shrubs including big sagebrush (Artemisia tridentata), littleleaf mountain mahogany (Cercocarpus intricatus), cliffrose (Cowania mexicana), antelope bitterbrush (Purshia tridentata), cliff fendlerbush (Fendlera rupicola), and roundleaf buffaloberry (Shepherdia rotundifolia)(Brotherson et al. 1980).

\section{Methods}

Sixteen 50-m transects were placed perpendicular to the fenceline enclosing Navajo National Monument where topography, vegetation, and soil appeared comparable. Eight transects were placed inside the monument boundary where grazing has been excluded for the past 40 years, and another 8 transects were placed outside the monument fence adjacent to those within the fence. Sampling was started $10 \mathrm{~m}$ from the fence. Grazing outside the monument boundary has occurred since the late 1890 's with sheep and since the early 1960's with sheep and cattle. Grazing is year round with the greatest utilization of the range being from early spring until late fall. Grazing pressures are moderate to heavy.

Ten quadrats $\left(0.25 \mathrm{~m}^{2}\right)$ were distributed along the transects at 5-m intervals. Each quadrat was subdivided into 4 sections of equal size. Percent cover of vascular and nonvascular species was estimated using the ocular method and cover classes proposed by Daubenmire (1959). Nonvascular cover was estimated and subdivided into 6 classes (lichens, mosses, algae, litter, soil, and rock) and recorded (Anderson et al. 1982b). Rock was included if its diameter was greater than $2.5 \mathrm{~cm}$. Frequency for all vascular and nonvascular species as well as the above listed general categories was also computed. This was done by noting the total number of quadrat sections within which a species or a general category occurred and then dividing this number by the total number of 
Table 1. Mean percent and standard deviation of cover categories for grazed and nongrazed areas in Navajo National Monument.

\begin{tabular}{|c|c|c|c|c|c|}
\hline \multirow{2}{*}{$\begin{array}{l}\text { Cover } \\
\text { category }\end{array}$} & \multicolumn{2}{|c|}{ Grazed } & \multicolumn{2}{|c|}{ Nongrazed } & \multirow{2}{*}{$\begin{array}{c}\text { Signifi- } \\
\text { cance } \\
\text { level }\end{array}$} \\
\hline & Mean & S.D. & Mean & S.D. & \\
\hline$\overline{\text { Algae }}$ & 13.8 & 15.5 & 32.7 & 18.3 & 0.05 \\
\hline Moss & 1.1 & 1.1 & 6.8 & 5.6 & 0.025 \\
\hline Lichen & 2.5 & 3.0 & 14.1 & 9.0 & 0.01 \\
\hline Vascular plants & 21.4 & 11.2 & 26.0 & 18.5 & NS \\
\hline Litter & 30.2 & 12.3 & 26.2 & 11.6 & NS \\
\hline Soil & 41.3 & 20.5 & 14.7 & 10.1 & 0.01 \\
\hline Rock & 0.1 & 0.2 & 11.3 & 16.7 & 0.05 \\
\hline
\end{tabular}

quadrat sections taken. The sum of all cover values often exceeded $100 \%$ due to overlaps encountered in the sampling. The general importance of vascular plant life forms (trees, shrubs, grasses, and forbs) was computed by numerically summing the average percent cover across all transects of all species falling into one of the life form groups. Differences between the cover categories for grazed and nongrazed areas were evaluated using Students $t$-tests.

\section{Results and Conclusions}

Cover characteristics of vascular and nonvascular communities are presented in Tables 1-4. Our results demonstrate important impacts of grazing animals (through both grazing and trampling) upon the vascular and nonvascular cryptogamic communities with the nonvascular communities showing significant damage (Table 1). Data on the cryptogamic crusts showed strong differences between the paired grazed and nongrazed areas. The areas subject to grazing supported significantly less cryptogamic cover including algae, lichens, and mosses (Table 1). The lichens and mosses were the most heavily reduced by grazing activity. Algae were much more tolerant of grazing disturbance. This was also shown by Anderson et al. (1982a). When individual species of mosses and lichens were considered, the above patterns repeated themselves with almost all identifiable species showing reduced numbers as well as reduced importance in the areas subject to grazing pressure (Table 2).

Table 2. Mean percent cover values and standard deviations for cryptogamic species growing on grazed and nongrazed soils in Navajo National Monument.

\begin{tabular}{|c|c|c|c|c|}
\hline \multirow[b]{2}{*}{ Species } & \multicolumn{2}{|c|}{ Grazed } & \multicolumn{2}{|c|}{ Nongrazed } \\
\hline & Mean & S.D. & Mean & S.D. \\
\hline & \multicolumn{4}{|c|}{ Mosses } \\
\hline Bryum sp. & 0.1 & 0.2 & 0.6 & 1.0 \\
\hline Grimmia ovalis & & & 0.1 & 0.2 \\
\hline Grimmia sp. & & & 0.4 & 0.7 \\
\hline \multirow[t]{2}{*}{ Tortula ruralis } & 1.0 & 1.1 & 6.3 & 6.2 \\
\hline & \multicolumn{4}{|c|}{ Lichens } \\
\hline Acrospora chloroplana & & & 0.1 & 0.1 \\
\hline Candelariella sp. & & & 0.3 & 0.5 \\
\hline Collema sp. & 1.4 & 2.6 & 8.1 & 12.4 \\
\hline Collema tenax & 0.4 & 0.7 & 0.8 & 1.4 \\
\hline Fulgensia sp. & & & 0.4 & 0.5 \\
\hline Lecanora crenulata & r. & & 1.2 & 2.2 \\
\hline Lecanora sp. & & & 0.4 & 1.2 \\
\hline Lecidea decipiens & & & 0.1 & 0.1 \\
\hline Lecidea sp. & & & 1.3 & 2.8 \\
\hline Lecidea tessellata & & & 0.2 & 0.5 \\
\hline Lepraria sp. & & & 0.1 & 0.1 \\
\hline Lichen sp. 1 & 0.2 & 1.0 & 1.3 & 1.3 \\
\hline Lichen sp. 2 & 0.1 & 0.1 & 0.2 & 0.3 \\
\hline Lichen sp. 3 & 0.1 & 0.1 & 0.1 & 0.1 \\
\hline Lichen sp. 4 & 0.1 & 0.2 & 1.0 & 1.2 \\
\hline Toninia caeruleonigricans & & & 0.1 & 0.2 \\
\hline Usnea sp. & & & 0.1 & 0.1 \\
\hline Xanthoria elegans & & & 0.1 & 0.1 \\
\hline
\end{tabular}

Percent of exposed soil in the grazed areas showed significant increase over nongrazed areas. This was largely due to the decreased importance of the cryptogamic crusts on these sites. Although rock cover was significantly higher in the nongrazed areas, this was not due to any animal impact but to the chance presence of more slickrock along one of the transects in the nongrazed sites. Also in the grazed areas the soil was loose and therefore more easily moved about by wind to cover exposed rocks.

The vascular plant and litter cover categories showed no significant difference between the areas (Table 1). However, differences were detected when individual species and plant life form categories were examined. Slenderbush eriogonum (Eriogonum microthecum), slender gilia (Gilia leptomeria), and sandhill muhly (Muhlenbergia pungens) had greater average cover values in the grazed areas while prickly gilia (Leptodactylon pungens), brittle pricklypear (Opuntia fragilis), Indian rice grass (Oryzopsis hymenoides), and longtongue muttongrass (Poa longiligula) had higher cover values in the nongrazed areas (Table 3). Analysis by life form indicated little or no difference in cover between the paired areas for trees, shrubs, and forbs. However, grasses had nearly $21 / 2$ times more cover in the nongrazed than in the grazed areas (Table 4). The frequency values also confirm the above conclusions.

The results of this study suggest that cryptogamic cover on pinyon-juniper ranges of northern Arizona is reduced by domestic

Table 3. Mean percent cover values and standard deviations for vascular plant species growing on grazed and nongrazed areas in Navajo National Monument.

\begin{tabular}{|c|c|c|c|c|}
\hline \multirow[b]{2}{*}{ Species } & \multicolumn{2}{|c|}{ Grazed } & \multicolumn{2}{|c|}{ Nongrazed } \\
\hline & Mean & S.D. & Mean & S.D. \\
\hline $\begin{array}{l}\text { Trees: } \\
\text { Juniperus osteosperma } \\
\text { Pinus edulis }\end{array}$ & $\begin{array}{l}2.9 \\
4.4\end{array}$ & $\begin{array}{l}4.1 \\
5.6\end{array}$ & $\begin{array}{l}1.7 \\
4.6\end{array}$ & $\begin{array}{l}3.4 \\
5.5\end{array}$ \\
\hline $\begin{array}{l}\text { Shrubs: } \\
\text { Artemisia tridentata } \\
\text { Chrysothamnus nauseosus } \\
\text { Echinocereus triglochidiatus } \\
\text { Eriogonum microthecum } \\
\text { Fendlera rupicola } \\
\text { Leptodactylon pungens } \\
\text { Opuntia fragilis } \\
\text { Opuntia polycantha } \\
\text { Xanthocephalum sarothrae } \\
\text { Yucca angustissima }\end{array}$ & $\begin{array}{l}2.7 \\
0.4 \\
2.7 \\
0.2 \\
0.9 \\
0.2 \\
0.1\end{array}$ & $\begin{array}{l}3.4 \\
1.1 \\
\\
3.7 \\
0.6 \\
2.1 \\
0.3 \\
0.2\end{array}$ & $\begin{array}{l}0.1 \\
1.5 \\
0.2 \\
2.0 \\
2.8 \\
0.4 \\
0.2 \\
0.1\end{array}$ & $\begin{array}{l}0.2 \\
2.8 \\
0.5 \\
2.6 \\
4.9 \\
1.1 \\
0.5 \\
0.2\end{array}$ \\
\hline $\begin{array}{l}\text { Forbs: } \\
\text { Androsace septentrionalis } \\
\text { Artemisia frigida } \\
\text { Astragalus convallarius } \\
\text { Aster arenosus } \\
\text { Delphinium nelsonii } \\
\text { Epilobium hornemannii } \\
\text { Eriogonum alatum } \\
\text { Fritillaria atropurpurea } \\
\text { Penstemon comarrhenus } \\
\text { Penstemon eatonii } \\
\text { Stephanomeria tenuifolia } \\
\text { Tradescantia occidentalis } \\
\text { Unknown seedlings }\end{array}$ & $\begin{array}{l}0.1 \\
\\
0.2 \\
0.1 \\
0.1 \\
0.3 \\
0.8\end{array}$ & $\begin{array}{l}0.2 \\
0.3 \\
0.2 \\
0.2 \\
0.5 \\
0.8\end{array}$ & $\begin{array}{l}0.1 \\
0.4 \\
0.1 \\
0.9 \\
0.2 \\
0.3 \\
\\
0.1 \\
0.1\end{array}$ & $\begin{array}{l}0.2 \\
0.5 \\
0.2 \\
1.5 \\
0.5 \\
0.5\end{array}$ \\
\hline $\begin{array}{l}\text { Grasses: } \\
\text { Bouteloua gracilis } \\
\text { Muhlenbergia pungens } \\
\text { Oryzopsis hymenoides } \\
\text { Poa longiligula } \\
\text { Stipa comata }\end{array}$ & $\begin{array}{l}2.0 \\
1.4 \\
0.8 \\
0.2 \\
0.1\end{array}$ & $\begin{array}{l}4.0 \\
3.4 \\
1.5 \\
0.2 \\
0.2\end{array}$ & $\begin{array}{l}3.5 \\
0.6 \\
1.4 \\
4.5 \\
0.5\end{array}$ & $\begin{array}{l}4.7 \\
1.6 \\
1.8 \\
5.5 \\
1.0\end{array}$ \\
\hline $\begin{array}{l}\text { Annuals: } \\
\text { Descurainia pinnata } \\
\text { Gilia leptomeria } \\
\text { Heterotheca villosa } \\
\text { Mentzelia albicaulis }\end{array}$ & $\begin{array}{l}0.2 \\
2.1 \\
2.5 \\
0.1\end{array}$ & $\begin{array}{l}0.4 \\
2.4 \\
3.7 \\
0.2\end{array}$ & $\begin{array}{l}0.4 \\
0.9 \\
3.6\end{array}$ & $\begin{array}{l}0.4 \\
1.1 \\
6.8\end{array}$ \\
\hline
\end{tabular}


Table 4. Percent sum cover and frequency values for vaseular plant life form growing on grazed and nongrazed areas in Navajo National Monument.

\begin{tabular}{lccccc}
\hline \hline & \multicolumn{2}{c}{ Cover } & & \multicolumn{2}{c}{ Frequency } \\
\cline { 2 - 3 } \cline { 6 - 6 } Life form & Grazed & Nongrazed & & Grazed & Nongrazed \\
\hline Trees & 7.3 & 6.3 & & 20.0 & 14.1 \\
Shrubs & 7.4 & 9.0 & & 35.6 & 37.1 \\
Grasses & 4.5 & 10.5 & & 27.3 & 44.0 \\
Forbs & 6.9 & 7.5 & & 40.9 & 43.6 \\
\hline
\end{tabular}

animal grazing activity. Further research is suggested in other areas and ecosystems. Mosses and lichens appear to be more affected than algae. Both total cover and the number of species in the cryptogamic community decreased under grazing. New and improved management practices are needed which consider the value of cryptogamic crust cover which is important in rangeland protection. Management techniques favoring the maintenance of cryptogamic crusts are not well worked out. However, Anderson et al. (1982b) indicated that such management practices are possible and should take into account the timing of grazing use to avoid the season of low precipitation, high temperature, and the incidence of torrential rains. They reason that this is the time period when the cryptogamic crusts are in an inactive state and thus are the most likely to be damaged by disturbance. Further, it appears that periods of rest enhance the reestablishment of cryptogamic cover and therefore management schemes should provide for such periods. Future research should include analyses of cryptogamic crust maintenance and the relationship between crusts and established grazing systems.

\section{Literature Cited}

Anantani, Y.S., and D.V. Marathe. 1974. Soil aggregating effects of some algae occurring in the soils of Kutch and Rajasthan. J. Univ. of Bombay 41(68);99-100.

Anderson, D.C., K.T. Harper, and S.R. Rushforth. 1982a. Recovery of cryptogamic crusts from grazing on Utah winter ranges. J. Range Manage. 35:355-359.

Anderson, D.C., K.T. Harper, and R.C. Holmgren. 1982b. Factors influencing development of cryptogamic soil crusts in Utah deserts. J. Range Manage. 35:180-185.

Anderson, D.C., and S.R. Rushforth. 1976. The cryptogamic flora of desert soil crusts in southern Utah. Nova Hedwigia 28:691-729.

Brotherson, J.D., W.E. Evenson, S.R. Rushforth, J. Fairchild, and J. Johansen. 1980. Spatial patterns of plant communities in Navajo National Monument, Arizona. In: Ecological Studies at Navajo National Monument Part II. A report for the National Park Service Southwest Region and Navajo National Monument.

Daubenmire, R. 1959. A canopy-coverage method of vegetational analysis. Northwest Sci. 33:43-64.

Fletcher, J.E., and W.P. Martin. 1948. Some effects of algae and molds in the rain-crust of desert soils. Ecology 29:95-100.

Hack, J.T. 1945. Recent geology of the Tsegi Canyon. Appendix I, In: R.L. Beals, G.W. Brainerd, and W. Smith, (Eds.) Archeological studies in northeast Arizona. University Calif. Press, Berkeley and Los Angeles.

Kleiner, E.F., and K.T. Herper. 1972. Environment and community organization in grasslands of Canyonlands National Park. Ecology 53:229-309.

Kleiner, E.F., and K.T. Harper. 1977. Soil properties in relation to cryptogamic ground cover in Canyonlands National Park. J. Range Manage. 30:202-205.

Loope, W.L., and G.F. Gifford. 1972. Influence of a soil microfloral crust on select properties of soils under pinyon-juniper in southeastern Utah. J. Soil and Water Conserv. 27:164-167.

Rychert, R.C., and J. Skujins. 1974. Nitrogen fixation by blue-green algaelichen crusts in the Great Basin Desert. Soil Sci. Soc. of Amer. Proc. 38:768-77I.

\section{Don't miss the 1984 Annual Meeting of the Society for Range Management February 12-17, 1984 in Rapid City, South Dakota}

